\title{
Evaluation of the Antiviral Activity of Propolis from Native Bees (Plebeia frontalis) against Canine Distemper Virus
}

\section{Olga Valeria Domínguez Jiménez¹, Betsabé Rodríguez Pérez ${ }^{2}$, Tonatiuh Alejandro Cruz Sánchez², Carlos Gerardo García Tovar ${ }^{1}$, José Luis Nieto Bordes ${ }^{1}$, Carlos Ignacio Soto Zárate ${ }^{{ }^{*}}$}

\author{
${ }^{1}$ Laboratorio 4 de Morfología Veterinaria y Biología Celular, Unidad de Investigación Multidisciplinaria (UIM), Facultad de \\ Estudios Superiores Cuautitlán, UNAM, Cuautitlán Izcalli, México \\ ${ }^{2}$ Laboratorio 6 de Bioprospección Microbiológica, Unidad de Investigación Multidisciplinaria (UIM), Facultad de Estudios \\ Superiores Cuautitlán, UNAM, Cuautitlán Izcalli, México \\ Email: *cisz2012@gmail.com
}

How to cite this paper: Jiménez, O.V.D., Pérez, B.R., Sánchez, T.A.C., Tovar, C.G.G., Bordes, J.L.N. and Zárate, C.I.S. (2020) Evaluation of the Antiviral Activity of Propolis from Native Bees (Plebeia frontalis) against Canine Distemper Virus. Open Journal of Veterinary Medicine, 10, 207-218. https://doi.org/10.4236/ojvm.2020.1012018

Received: October 14, 2020

Accepted: December 28, 2020

Published: December 31, 2020

Copyright () 2020 by author(s) and Scientific Research Publishing Inc. This work is licensed under the Creative Commons Attribution International License (CC BY 4.0).

http://creativecommons.org/licenses/by/4.0/

(c) (i) Open Access

\begin{abstract}
Propolis is a natural substance made from resins collected from trees and plants, and which bees combine with pollen, wax, and their own enzymes. It has a complex chemical composition that varies with the harvest season, vegetation type, bee species, and geographical region. Thanks to its components, it has valuable biological properties such as antifungal, antibacterial, anticancer, antiviral, and immunomodulatory activity. For this study, a sample of propolis harvested in April 2019 was used, which came from a bee native to Mexico (Plebeia frontalis) in whose geographical environment there are seven other native species. Canine distemper virus is an RNA virus that causes a systemic infection with high fatality rates in guests without protective immunity. In this work, the antiviral effect of Plebeia frontalis propolis on canine distemper virus was tested, administering it one hour before and simultaneously to infection. The antiviral effect was evaluated by determining cellular viability with the MTT assay. The results obtained show that this propolis has a statistically significant antiviral effect on both treatments, although it is slightly better when applied one hour before viral infection, so we can recommend it as an antiviral treatment in both domestic animals and human beings. There are currently few studies of the antiviral effect of propolis, this being the first study of a melliponium propolis in veterinary medicine.
\end{abstract}

\section{Keywords}

Propolis, Vero Cells, Antiviral Effect, Meliponines 


\section{Introduction}

Propolis is a resinous mixture that bees make from exudates (resins) gathered from different botanical sources and then modify them by adding salivary secretions. The mixture is transported to the inside of the hive and used by the bees as building material, sealant for unwanted holes and cracks, chemical defense against microorganisms and as an embalming agent for intruders that die inside the hive but cannot be removed by them due to their size [1]. Propolis is made of resin and vegetable balm (50\%), wax (30\%), essential and aromatic oils (10\%), pollen (5\%) and other substances (5\%), including organic wastes [2]. Propolis has a complex chemical composition and it varies according to the flora of its place of origin, the season at which recollection takes place, the type of vegetation, the bee species, and the geographical region. Several substances have been isolated from propolis: polysaccharide terpenes, aromatic acids, polyphenols, phenolic acids esters, minerals, vitamins and amino acids [3]. These substances give propolis several biological properties, such as: antifungal, antibacterial, immunomodulatory, anticarcinogenic and antiviral [4] [5]. A relevant precedent is the fact that, for a long time, propolis coming from native bees has been used in human healthcare for its antimicrobial and antioxidant properties [1].

Canine Distemper Virus (CDV) is RNA virus of the family Paramyxoviridae and measures $115-160 \mathrm{~nm}$ [6]. The virus has a single-stranded, non-segmented and negative-sense RNA genome that codifies various proteins; two surface glycoproteins (hemagglutinin and fusion protein), viral matrix protein, nucleocapsid protein, phosphoprotein and RNA polymerase [7]. CDV is characterized for giving rise to a systemic infection with high mortality rates in hosts that have no protective immunity. Its clinical manifestations include pyrexia, anorexia, nasal discharge, conjunctivitis, diarrhea, cutaneous pustules, hyperkeratosis, among others [8]. In a high percentage of infected animals, the central nervous system is affected, causing severe neurological complications due to infiltration of inflammatory cells and demyelination [9]. At the peak of the disease, the virus can be found in: oculonasal discharge, blood (with the first rise in temperature), content of vesicles and pustules, respiratory airways and spleen [6]. The disease affects several animal species worldwide. The presence of CDV has been confirmed in a great variety of animal families: Mustelidae (ferret), Canidae (fox, coyote, dog), Ursidae (bear), Felidae (wild felines), Procyonidae (raccoon), Japanese primates, Pinnipedia (sea lion, seals, fur seal) and dolphins [10] [11].

Previously, our research team has investigated the antiviral properties of Mexican propolis, produced by Apis mellifera, against pseudorabies virus and canine distemper virus; in all cases, promising results have been obtained [12] [13] [14]. In the present study, we evaluated the antiviral effect of propolis from native Mexican bees (Plebeia frontalis), on VERO cells-cultivated Canine Distemper Virus, using two different treatment times: an hour before infection and at the same time of infection. To this date and to our knowledge, no scientific reports have been made regarding the antiviral activity of propolis coming from 
native bees (Plebeia frontalis) and for this reason, the results here obtained represent an innovative and important scientific report in the area of human and animal medicine.

\section{Materials and Methods}

\subsection{Description of the Study Area}

A propolis sample from Coatepec, Veracruz was used (provided by Raquel Zepeda, INANA A. C.). This town is located at $19^{\circ} 27^{\prime}$ north, $96^{\circ} 58^{\prime}$ west, at an altitude of 1200 m.a.s.l., with a regular template-humid weather and an average temperature of $19.2^{\circ} \mathrm{C}$ [15]. The ecosystem is that of a mountain mesophile forest, that in México is characterized because its canopy consists predominantly of template climate deciduous trees (liquidambar, oaks, beeches and pine trees), while the understory is conformed mainly of evergreen tropical species (bushes from the families: Acanthaceae, Rubiaceae and Myrsinaceae). Epiphytes like orchids, bromeliads, peppers, and aroids abound on treetops. Arborescent ferns and the plenitude of epiphytes like bromeliads, ferns, orchids, and moss, are some of the characteristic elements of these forests [16] [17].

\subsection{Collection and Extraction of Propolis}

In the laboratory there are 27 samples from the same geographical area and harvested in April 2019, these samples are divided, number in parentheses, among the following species: Scaptotrigona mexicana (8), Nannotrigona perilampoides (5), Melipona beecheii (3), Scaptotrigona pectoralis (3), Partamona orizabensis (2), Plebeia melánica (1), Plebeia frontalis (2) and Plebeia sp (3). To carry out this study, the sample with the highest content of phenolic and flavonoid compounds was chosen, so one of the propolis from Plebeia frontalis was used. Propolis ethanolic extract (PEE) was obtained from 50 grams of raw propolis, which was previously crushed and cleaned of impurities (wood shavings, net remains, dead bees, among other things), $100 \mathrm{ml}$ of $70 \%$ ethanol were added and the resultant mixture was subjected to extraction by means of a ultrasonicator (Branson, CPX1800H, Danbury, USA), the resultant product was then filtrated using a vacuum filtration system. Finally, the obtained filtrate was concentrated using a rotary evaporator (Science MED, SM100-PRO, Finland) and was left to dry by vacuum pump. The dry PEE was then protected from light and refrigerated at $4^{\circ} \mathrm{C}$ until use [18].

\subsection{Content of Phenolic Compounds}

Determination of phenolic compounds was accomplished using a Folin-Ciocalteu assay. Used reagents and solvents were acquired from Sigma-Aldrich. Samples that were going to be evaluated were prepared at a concentration of $0.05 \mathrm{mg} / \mathrm{mL}$. For determination of phenolic compounds, a calibration curve was made at a concentration range of $6.25-200 \mu \mathrm{g} / \mathrm{mL}$, using gallic acid as the standard (Sigma-Aldrich). For this $6 \mathrm{ml}$ of distilled water and $500 \mu \mathrm{L}$ of Folin-Ciocalteu rea- 
gent were added to $1 \mathrm{ml}$ of PEE, the mix was allowed to react for 5 minutes; 1.5 $\mathrm{ml}$ of $20 \% \mathrm{Na}_{2} \mathrm{CO}_{3}$ were added and then distilled water, until $10 \mathrm{ml}$ were reached. The mixture was left to react for 2 hours and the absorbances of the samples were measured at a wavelength of $760 \mathrm{~nm}$ by UV-VIS absorption spectrophotometry (DLAB, SP-UV1000, China). Phenolic compounds were expressed as a percentage (\%) [18].

\subsection{Flavonoid Content}

Flavonoid content was determined by means of the aluminum chloride $\left(\mathrm{AlCl}_{3}\right)$ colorimetric assay. Used reagents and solvents were acquired from Sigma-Aldrich. In order to determine flavonoid content, a calibration curve was made, with a concentration range of $1-90 \mu \mathrm{g} / \mathrm{mL}$, using quercetin as the standard reference. For this $1 \mathrm{ml}$ of reagent-graded methanol and $1 \mathrm{ml}$ of $2 \% \mathrm{AlCl}_{3}$ were added to 1 $\mathrm{ml}$ of the PEE solution $(0.05 \mathrm{mg} / \mathrm{mL})$, The mixture was allowed to react for 10 minutes and the absorbance was determined at a wavelength of $415 \mathrm{~nm}$ by UV-VIS absorption spectrophotometry (DLAB, SP-UV1000, China). Results were expressed as a percentage (\%) [18].

\subsection{Cellular Line and Virus}

Monolayers of Vero cells (African green monkey kidney) were kept in DMEM (Dulbecco's Modified Eagle Medium), the medium was supplemented with 7\% bovine fetal serum and antibiotic (penicillin-streptomycin), and was kept at $37^{\circ} \mathrm{C}$ in a humidified atmosphere, $95 \%$ air and $5 \% \mathrm{CO}_{2}$. The Buzzel strain of Canine Distemper Virus, kept at $-20^{\circ} \mathrm{C}$, was used to infect the cells, using a viral concentration of $10^{12.16}\left(\mathrm{TCID}_{50}=10^{12.16} / \mathrm{mL}\right)$ [19] [20].

\subsection{Cytopathic Effect and Identification of the CDV by Immunofluorescence}

Vero cells were grown on sterile coverslips inside $60 \mathrm{~mm}$ Petri dishes, two groups were formed; negative control (uninfected) and positive control, the latter was inoculated with $100 \mu \mathrm{L}$ of the viral solution; both groups were incubated for 72 hours, at which time the medium was discarded and the cells were fixed using $10 \%$ formalin prepared in PBS for 20 minutes, washes were performed with PBS. At the end, cultures were observed by inverted microscopy and photographed using a digital camera. After this, the necessary steps to complete the immunofluorescent assay were preformed; for this purpose, cells were permeabilizated using Triton X-100 (0.5\%) for 5 minutes. Next, PBS washes took place and the cells were blocked using bovine serum albumin (1\% in PBS) for 20 minutes, followed by another wash with PBS, and then the cells were incubated with the viral antibody, Canine Distemper Virus Mab (VMRD, cat. CJ-F-CDV-MAB-1ML), for 12 hours at $4^{\circ} \mathrm{C}$. Once this time had elapsed, washes were performed, first with PBS and, finally, with double distilled water. Coverslips were mounted (U1traCruz Mounting Medium for fluorescence with DAPI, Santa Cruz Biotechnology, cat. sc-24941), edges were sealed and then kept in refrigeration. Finally, 
they were observed by fluorescence microscopy (Carl Zeiss, mod. axioscope) [20] [21].

\subsection{Cytotoxicity Assay}

Mean cytotoxic concentration was determined by means of tetrazolium dye (MTT) colorimetric assay; for this, VERO cells were seeded at a density of $2.4 \times$ $10^{4}$ cells/well, in 96-well plates, the plates were then incubated for 24 hours, and then PEE diluted in DMEM-acetone $(1 \mathrm{~mL} / 30 \mu \mathrm{L}$, respectively) was added at different concentrations $(2,1,0.5,0.25,0.125 \mathrm{mg} / \mathrm{mL})$. Cells were incubated for another 72 hours, then a viability colorimetric assay was performed; for this, 10 $\mu \mathrm{L}$ of MTT per well were added, followed by a 4 hours incubation period, at which time the medium was discarded and $100 \mu \mathrm{L}$ of dimethyl sulfoxide were added; 15 minutes after, readings were made using an ELISA reader (595 nm). Obtained values were plotted so as to determine the mean cytotoxic concentration $\left(\mathrm{CC}_{50}\right)$, as well to determine the concentration to be used in the infection assays, so that a cellular viability of about $80 \%$ could be guaranteed [22].

\subsection{Antiviral Activity Evaluation}

PEE antiviral activity was evaluated in vitro using VERO-cell monolayers in 96-well ELISA plates. For infection, $30 \mu \mathrm{L}$ of the viral suspension were put into each well and the treatment consisted of $100 \mu \mathrm{L}$ of propolis $(0.3 \mathrm{mg} / \mathrm{mL}$ of DMEM). The treatment was administered at two points; one hour before infection and at the same time of infection. In both cases, cultures were evaluated 72 hours post infection by a viability colorimetric assay (MTT), which has been already described [12].

\subsection{Statistical Analysis}

Absorbances obtained were analyzed for each of the treatments and controls to evaluate the antiviral effect of PEE. The data obtained were processed by program Minitab (18 version, Spanish) by an ANOVA test (0.05 significance).

\section{Results}

\subsection{Propolis Composition}

The results of Folin-Ciocalteau and aluminum chloride colorimetric assays showed that the propolis that was used for the present study has a total phenol concentration of $5.34 \%$, and a flavonoid concentration of $3.5 \%$. All of the analytical tests implemented during the study were based according to the parameters established by the Mexican Official Norm: Propolis, production and specifications of its processing: NOM-003-SAG/GAN-2017 [18].

\subsection{Cytotoxic Concentration $\left(\mathrm{CC}_{50}\right)$ of Propolis}

VERO cell cultures were exposed to increasing concentrations of PEE to determine its level of toxicity. Through the colorimetric MTT assay, a cellular viabili- 
ty curve was made, and the median cytotoxic concentration $\left(\mathrm{CC}_{50}\right)$ was determined to be at $0.5 \mathrm{mg} / \mathrm{ml}$. The concentration to be used during infection trials was also determined, this being $0.3 \mathrm{mg} / \mathrm{mL}$, such concentration guarantees an $80 \%$ cellular viability.

\subsection{Cytopathic Effect of CDV}

Infected Vero cell cultures were evaluated at 72 hours post infection (hpi) under the inverted microscope. In the non-infected culture, cells displayed normal cellular morphology and growth, observing a monolayer with a confluence of above $80 \%$ (Figure 1(a)). On the other hand, when analyzing the infected cultures, cellular debris was observed, as well as loss of adhesion and a decreased cellular density, being this the result of the cellular lysis caused by the virus (Figure $1(\mathrm{~b}))$.

\subsection{Identification}

The presence of CDV in infected cultures was determined by a direct immunofluorescence assay. Observation of infected cultures by fluorescence microscopy allowed us to document areas of green color (Figure 2(a)), these areas were the result of the presence of anti-CDV antibodies that were marked with fluorescein; in contrast, in the uninfected cellular culture, no color emission was appreciated (Figure 2(c)). To confirm the presence of actual cells in both preparations, nuclei were marked by DAPI (blue color) fluorescent stain (Figure 2(b) and Figure $2(d))$. In both preparations, we can point out the presence of cells, as shown by the stained nuclei; the nuclei are pleomorphic in the infected cells due to the cellular damage caused by CDV.

\subsection{Evaluation of the Antiviral Activity}

The antiviral activity of the treatments used was determined with the colorimetric MTT assay. Obtained data are the result of multiple repetitions $(n=20)$; for noninfected cells a median of 0.426 was obtained, and for infected cells the obtained value was 0.156; whereas the values obtained for the treatments where: a value of 0.288 was obtained when the treatment was administered an hour

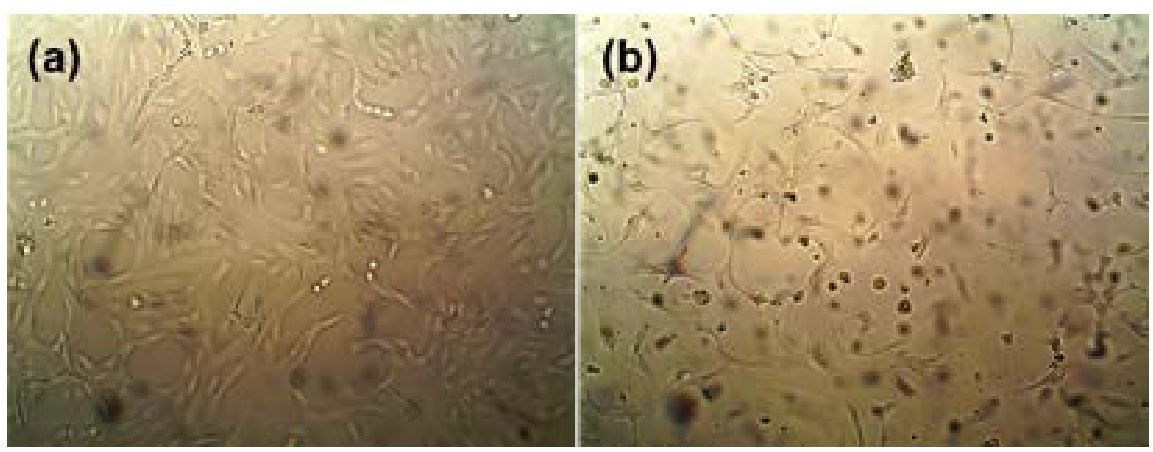

Figure 1. VERO cell monolayers. (a) Uninfected culture; (b) Culture infected by Canine Distemper Virus (100 $\mu$ of viral solution), 72 hpi. Inverted Microscopy (250×). 
before infection, and a value of 0.258 when the treatment was administered at the same time of infection. The values were analyzed by an ANOVA test $(\mathrm{p}=$ 0.05 ), the infected culture presented statistically significant differences between treatments and the uninfected culture. From this, we can point out that the implemented treatments exhibit a statistically significant antiviral effect (Figure 3).

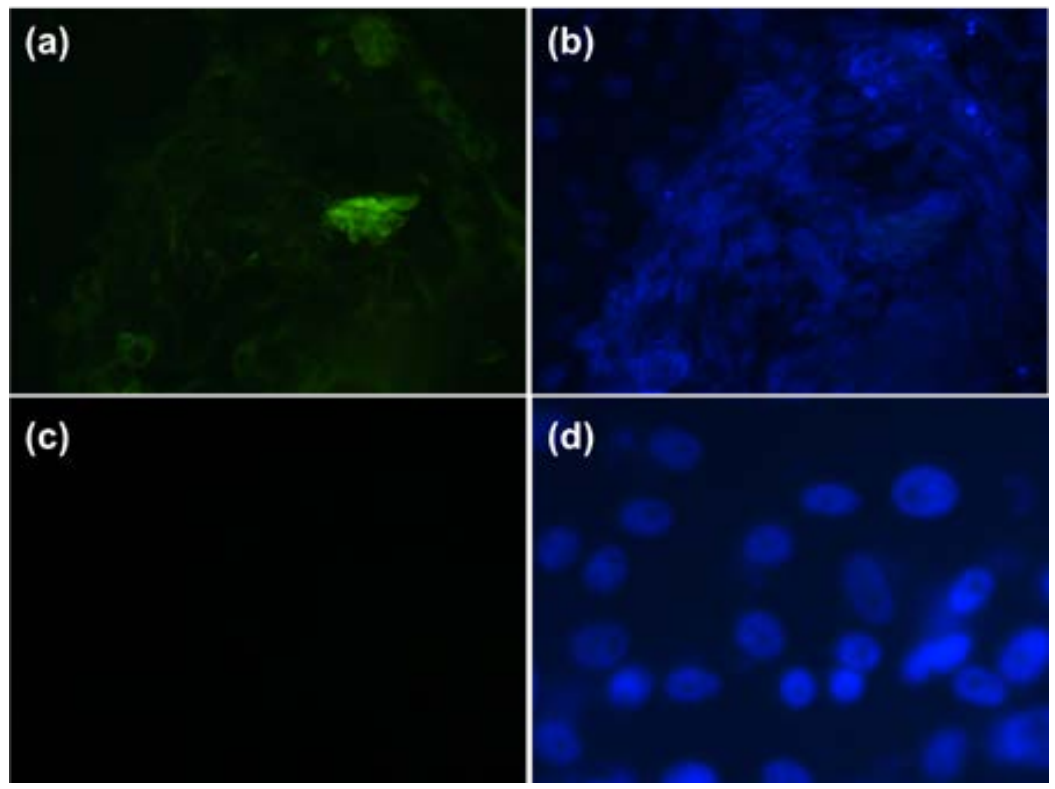

Figure 2. Canine Distemper Virus detection by immunofluorescence. (a) Infected VERO cells that were exposed to the anti-CDV antibody. A positive fluorescent signal can be appreciated; (b) Same preparations as in panel (a), now exposed to UV light in order to show the presence of cells by detecting their nuclei using a DAPI stain; (c) Uninfected VERO cells. Absence of a fluorescent signal is observed; (d) Same preparations as in panel (c), now exposed to UV light to show the actual presence of cells. Fluorescent microscopy $(400 \times)$.

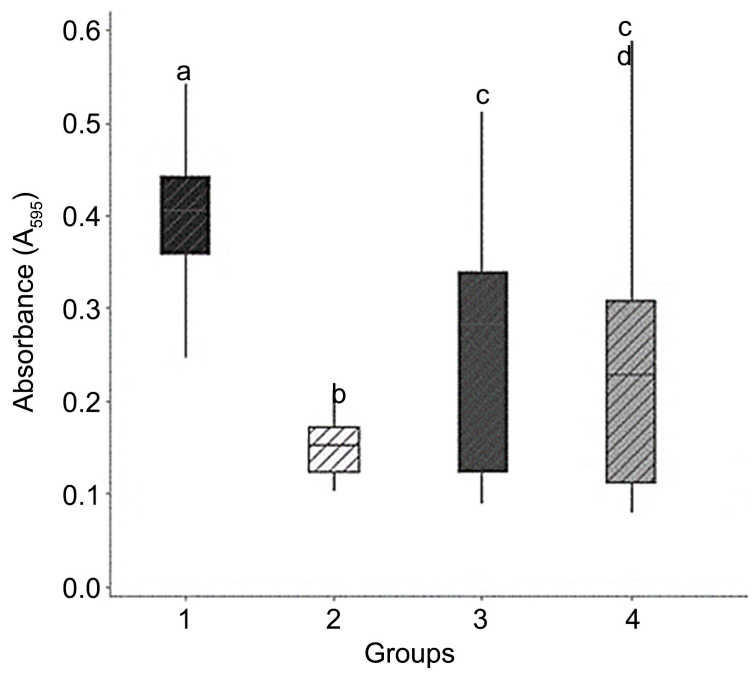

Figure 3. Evaluation of the antiviral activity of the PEE. The variance analysis is shown, with an ANOVA factor for each treatment. (1) Uninfected cultures; (2) Infected cultures; (3) Treatment one hour after infection; (4) Treatment at the same time of infection. 


\section{Discussion}

Propolis chemical composition is extremely variable, and thus, its specific components, and the amount of each one of them, are related to the type of climate, vegetation of the geographic location and the predilection of the bees at the moment of recollection. For these reasons, propolis composition varies according to the site of origin, season of the year, and, not less important, the bee-species involved in its recollection [14]. Additionally, method of recollection and post-harvest handling are also crucial factors regarding the presence of active compounds present in the final propolis extract. Since the biologically active components of propolis are mainly polyphenolic and aromatic compounds, as well as flavonoids, the use of high polarity solvents is a good way of achieving higher performances, which translates into a superior antioxidant activity [23].

Propolis resinous fraction is integrated by phenolic compounds and flavonoids, which are very important when talking about the therapeutic properties of propolis, and present a synergistic effect that is essential for the beneficial biological activities, both in humans and animals: antibacterial, antifungal, antiviral, antioxidant, immunomodulatory, among others [24] [25].

Phenolic compounds, among which we can find flavonoids, represent a quality index of propolis, the higher its content (percentage), the greater the purity and quality of propolis [25]. For this reason, it is important to determine the content of phenols and flavonoids for each propolis. Propolis used for the present study was determined to have a $5.34 \%$ content of phenols and $3.5 \%$ of flavonoids. When comparing these values to those reported by other authors for propolis coming from Apis mellifera that on average contain 23.6\% phenols and 6.7\% flavonoids [13] [14], it is evident that propolis coming from Plebeia frontalis presents lower contents of both phenols and flavonoids; however, when comparing the antiviral activity of both, we can say that obtained results are equivalent.

In spite of the fact that for most CDV strains, such as Ledeerle, Rockborn and Onderstepoort, VERO-cell cellular lysis has not been reported. For the present study, it was accomplished that the Buzzel strain, after several passages, formed syncytium at $24 \mathrm{hpi}$ and lytic plaques at $48 \mathrm{hpi}$, in the previously mentioned cellular line. In the present article, an evident cytopathic effect was documented at 72 hpi (Figure 1(b)), which goes to show the fact that this specific strain of the virus culminates its infection causing cellular lysis [26]. This particular feature allowed us to implement a MTT colorimetric assay in order to evaluate the performance of the applied treatments, through determination of cellular viability.

With the purpose of having a better understanding of the antiviral activity of propolis, during the infection assays, that is, during the interaction between virus, cells and propolis, two different moments of treatment administration were used: one hour before infection and at the same time of infection. In both cases, evaluation by MTT assay was performed at $72 \mathrm{hpi}$. According to the obtained results, we can point out that propolis presents statistically significant antiviral effect, and this effect is slightly superior when treatment is applied 1 hour before 
viral infection; nonetheless, a significant difference is also appreciated in cultures treated with propolis at the same time of infection, when compared to the positive control.

These results are in agreement with that noted by other authors, who point out that the antiviral activity of propolis is mainly due to the interference with superficial structures of the virion (glycoproteins), and with the cellular receptors, during the first stages of viral infection, thus avoiding the adsorption, union and penetration of the virus into the cells [27] [28] [29] [30] [31]. All of this is reinforced by the fact that, when propolis is applied 2 hours after infection, only a slight antiviral effect in noted [12], although this remains to be corroborated with propolis coming from Plebeia frontalis. Additionally, it has already been demonstrated that flavonoids are also capable of inhibiting viral polymerase and thus interfere with nucleic acid synthesis [32] [33] [34] [35].

There are currently few studies on the antiviral effect of propolis, the present study being the first one about propolis from meliponines in veterinary medicine. The results obtained indicate that the PEE from native Mexican bees (Plebeia frontalis, specifically) may be an important option when implementing an antiviral treatment in both, domestic animals and human beings. However, to fully characterize the antiviral activity of this propolis, it is necessary to test its activity in other viral families and evaluate aspects complementary to the results obtained in this work as; to document changes in adsorption, binding, and penetration of viruses by transmission electron microscopy and possible changes in the gene expression of the virus by retrotranscription and PCR.

\section{Conclusion}

Propolis ethanolic extract from Plebeia frontalis showed a statistically significant antiviral effect in VERO cell cultures infected with the canine distemper virus and this effect was similar when was applied an hour before and simultaneously to the infection. Therefore, it is advisable to consider it within an antiviral therapy in both, domestic animals and human beings.

\section{Acknowledgements}

We thank M. en C. Raquel Zepeda from INANA A. C. for providing the propolis used in this study and support given by project PAPIT, code IN223719 (DGAPA-UNAM) and projects PIAPI 2050 and PIAPI 2011 (FES-Cuautitlán, UNAM).

\section{Conflicts of Interest}

The authors state that the present article has not been sent to, nor published by any other journal and that no conflict of interest exists.

\section{References}

[1] Rodríguez-Pérez, B., Canales-Martínez, M.M., Penieres-Carrillo, J.G., Cruz-Sánchez, 
T.A. (2020) Composición química, propiedades antioxidantes y actividad antimicrobiana de propóleos mexicanos. Acta Universitaria, 30, e2435. https://doi.org/10.15174/au.2020.2435

[2] Amini, S.N., Mobini, D.M., Khosravi, F.S. and Teimori, H. (2015) Anticancer Activity of Ethanolic Extract of Propolis on AGS Cell Line. Journal of Herbmed Pharmacology, 4, 29-34.

[3] Joya, M., Gil, M. and Bastidas-Pacheco, G. (2017) Actividad fungist Ática y fungicida de extractos etanólicos de propóleos sobre el crecimiento in vitro de cepas del género Candida. Tecnología en Marcha, 30, 3-11.

https://doi.org/10.18845/tm.v30i3.3268

[4] Freitas-Dos Santos, H., Ferreira-Campos, J., Miranda-Dos Santos, C., Perrella-Balestieri, J.B., Brentan-Silva, D., Alexandre-Carollo, C. and Lucas-Dos Santos, E. (2017) Chemical Profile and Antioxidant, Anti-Inflammatory, Antimutagenic and Antimicrobial Activities of Geopropolis from the Stingless Bee Melipona orbignyi. International Journal of Molecular Sciences, 18, 953. https://doi.org/10.3390/ijms18050953

[5] Shimizu, T., Takeshita, Y., Takamori, Y., Kai, H., Sawamura, R., Yoshida, H. and Kurokawa, M. (2011) Efficacy of Brazilian Propolis against Herpes Simplex Virus Type 1 Infection in Mice and Their Modes of Antiherpetic Efficacies. Evidence-Based Complementary and Alternative Medicine, 2011, Article ID: 976196. https://doi.org/10.1155/2011/976196

[6] Figueroa, M.V. (1984) Enfermedades infecciosas de los animales domésticos en Centroamérica. EUNED, San José.

[7] Sidhu, M.S. (1993) Canine Distemper Terminal and Intergenic Non-protein Coding Nucleotide Sequences: Completion of the Entire CDV Genome Sequence. Virology, 193, 66-72. https://doi.org/10.1006/viro.1993.1103

[8] Martella, V., Elia, G. and Buonavoglia, C. (2008) Canine Distemper Virus. Veterinary Clinics Small Animal Practice, 38, 787-797. https://doi.org/10.1016/j.cvsm.2008.02.007

[9] Summers, B. and Appel, M. (1994) Aspects of Canine Distemper Virus and Measles Virus Encephalomyelitis. Neuropathology and Applied Neurobiology, 20, 525-534. https://doi.org/10.1111/j.1365-2990.1994.tb01006.x

[10] Rentamal, P., Abalos, P. and Fredes, F. (2010) Enfermedades animales producidas por agentes biológicos. Editorial Universitaria, Santiago de Chile.

[11] Appel, M., Yates, R., Foley, G., Bernstein, J., Santinelli, S., Spelman, L. and Summers, B. (1994) Canine Distemper Epizootic in Lions, Tigers and Leopards in North America. Journal of Veterinary Diagnostic Investigation, 6, 277-288. https://doi.org/10.1177/104063879400600301

[12] González-Búrquez, M.D., González-Díaz, F.R., García-Tovar, C.G., Carrillo-Miranda, L., Soto-Zárate, C.I., Canales-Martínez, M.M. and Fonseca-Coronado, S. (2018) Comparison between in Vitro Antiviral Effect of Mexican Propolis and Three Commercial Flavonoids against Canine Distemper Virus. Evidence-Based Complementary and Alternative Medicine, 2018, Article ID: 7092416. https://doi.org/10.1155/2018/7092416

[13] Martinez-Bistrain, Y. (2017) Evaluación in vitro de la actividad antiviral de dos propóleos del Estado de México contra el virus del Distemper canino. Universidad Nacional Autónoma de México, México.

[14] González-Búrquez, M.D. (2013) Evaluación antiviral del propóleo Mexicano en cultivo celular infectado con el virus de Aujeszky. Tesis de Grado. Universidad 
Nacional Autónoma de México, México.

[15] H. Ayuntamiento de Coatepec (2020) Enciclopedia de los Municipios y Delegaciones de México. Estado de Veracruz.

[16] Challenger, A. (1998) Utilización y conservación de los ecosistemas terrestres de México. Pasado, presente y futuro. Comisión Nacional para el Conocimiento y uso de la Biodiversidad.

[17] Rzedowski, J. (2006) Vegetación de México. Comisión nacional para el conocimiento y Uso de la Biodiversidad.

[18] Diario Oficial de la Federación (2017) NORMA Oficial Mexicana NOM-003-SAG/ GAN-2017, Propóleos, producción y especificaciones para su procesamiento. México.

[19] Freshney, R.I. (2010) Culture of Animal Cells: A Manual of Basic Technique and Specialized Applications. 6th Edition, John Wiley \& Sons Ltd., Hoboken. https://doi.org/10.1002/9780470649367

[20] Mahy, B.W.J. and Kangro, H.O. (1996) Virology Methods Manual. Academic Press, Cambridge.

[21] Celis, J.E. (1997) Cell Biology: A Laboratory Handbook. 2nd Edition, Academic Press, Cambridge.

[22] Alamoudil, W.A., Ahmad, F., Acharya, S., Haque, S., Alsamman, K., Herzallah, H.K. and Al-Otaibi, S.T. (2018) A Simplified Colorimetric Method for Rapid Detection of Cell Viability and Toxicity in Adherent Cell Culture Systems. Journal of BUON, 23, 1505-1513.

[23] Park, H., Song H.B., Park, Y., Choi, H.S. and Suh H.J. (2015) Lipase-Mediated Lipid Removal from Propolis Extract and Its Antiradical and Antimicrobial Activity. Journal of the Science of Food and Agriculture, 95, 1697-1705. https://doi.org/10.1002/jsfa.6874

[24] Delgado-Aceves, M.D., Andrade-Ortega, J.A. and Ramírez-Barragán, C.A. (2015) Caracterización fisicoquímica de propóleos colectados en el Bosque La Primavera Zapopan, Jalisco. Revista Mexicana de Ciencias Forestales, 6, 74-87. https://doi.org/10.29298/rmcf.v6i28.270

[25] Rodríguez, B. (2015) Perfil Químico de propóleos mexicanos para su aplicación en medicina veterinaria. Tesis de Grado, Universidad Nacional Autónoma de México, México.

[26] Reyes, L.J., Santos, G., Hernández, J., Espinosa, B., Borraz, M.T., Ramírez, H., Vallejo, V. and Zenteno, E. (2002) Mecanismos moleculares de la patogenia viral: Estudios con el Rubulavirus porcino. Mensaje Bioquímico, 26, 99-125.

[27] Nolkemper, S., Reichling, J., Heinz Sensch, K. and Schnitzler, P. (2010) Mechanism of Herpes Simplex Virus Type 2 Suppression by Propolis Extracts. Phytomedicine, 17, 132-138. https://doi.org/10.1016/j.phymed.2009.07.006

[28] Bankova, V.G. (2014) Chemical Composition of Propolis Extract ACF and Activity against Herpes Simplex Virus. Phytomedicine, 21, 1432-1438. https://doi.org/10.1016/j.phymed.2014.04.026

[29] Hochheim, S., Guedes, A., Faccin Galhardi, L., Zendrini Rechenchoski, D., Nozawa, C., Linhares, R. E. and Mendes de Cordova, C.M. (2019) Determination of Phenolic Profile by HPLC-ESI-MS/MS, Antioxidant Activity, in Vitro Cytotoxicity and Anti-Herpetic Activity of Propolis from the Brazilian Native Bee Melipona quadrifasciata. Revista Brasileira de Farmacognosia, 29, 339-350.

https://doi.org/10.1016/j.bjp.2018.12.010

[30] Muñoz R.L., Linares V.S. and Narváez S.W. (2011) Propiedades del propóleo como 
un aditivo funcional en la nutrición animal. Biosalud, 10, 101-111.

[31] Carvalho, B.F. (2013) In Vitro Inhibition of Distemper Canine Virus by Flavonoids and Phenolic Acids. Implications of Structural Differences for Antiviral Design. Veterinary Science, 95, 717-724. https://doi.org/10.1016/j.rvsc.2013.04.013

[32] Formica, J. and Regelson, W. (1995) Review of Quercetin and Related Bioflavonoids. Food and Chemical Toxicology, 33, 1061-1080. https://doi.org/10.1016/0278-6915(95)00077-1

[33] Cushine, T. and Lamb, A. (2005) Antimicrobial Activity of Flavonoids. International Journal of Antimicrobial Agents, 26, 343-356. https://doi.org/10.1016/j.ijantimicag.2005.09.002

[34] Gallina, L., Dal Pozo, F., Galligioni, V., Bombardelli, E. and Scagliarini, A. (2011) Inhibition of Viral RNA Synthesis in Canine Distemper Virus Infection by Proanthocyanidin A2. Antiviral Research, 92, 447-452. https://doi.org/10.1016/j.antiviral.2011.10.004

[35] Park, H., Song, H.B., Park, Y., Choi, H.S. and Suh, H.J. (2015) Lipase-Mediated Lipid Removal from Propolis Extract and Its Antiradical and Antimicrobial Activity. Journal of the Science of Food and Agriculture, 95, 1697-1705. 